\title{
Effect of Subchronic Vitamin E Treatment on the Testes of Male Albino Rats
}

\author{
Eman E. ELaraby ${ }^{1}$, Heba N. Gad EL-Hak ${ }^{2 *}$, Ahmed K. Hassan ${ }^{1}$, Osama A. Abbas ${ }^{1}$ \\ ${ }^{1}$ Zoology department, faculty of Science, Port said university, Port said, Egypt. \\ ${ }^{2}$ Zoology department, faculty of Science, Suez canal university, Ismailia, Egypt.
}

Corresponding Author: Heba N. Gad EL-Hak, Zoology department, faculty of Science, Suez canal university, Ismailia, Egypt.

\begin{abstract}
Vitamin E is widely used as a drug supplement in many diseases. The aim of these investigations was conducted to study vitamin E supplement effect on testicular tissues in male albino rats after 90 days of repeated treatment and after stopping treatment for 45 days. Sevengroups of six male rats were orally administered 500, 1000 and $2000 \mathrm{mg} / \mathrm{kg}$ body weight vitamin E daily and the control received distilled water for 90 days. Testosterone and histological examination of testes were assessed. The elevation of the number of seminiferous containing sperm and not containing sperm was counted. The rats treated with two higher Vitamin E supplement dose treatment caused a significant increase in testosterone and seminiferous containing sperm. Therefore, oral administration of vitamin $E$ supplement in rats for 90 days was safe for the testis and has a spermatogenic effect. The androgenic effect of vitamin Epersists even stopping treatment.
\end{abstract}

Keywords: Vitamin E; testes histology; testosterone; fertility.

\section{INTRODUCTION}

Infertility is a major clinical problem, affecting people medically and psychosocially(1). Reduced male fertility can be the result of congenital and acquired urogenital abnormalities, infections of the male accessory glands, increased scrotal temperature, endocrine disturbances, genetic abnormalities and immunological factors (2). In 40-60\% of cases the only abnormality is the semen analysis and there is no relevant history or abnormality on physical examination and endocrine laboratory testing (idiopathic male infertility)(3). Semen analysis reveals a decreased number of spermatozoa (oligozoospermia), decreased motility (asthenozoospermia) and many abnormal forms on morphological examination (teratozoospermia). Usually, these abnormalities come together and are described as the OAT-syndrome (oligo-astheno-teratozoospermia) (4). Numerous studies have reported beneficial effects of antioxidant drugs and supplement on semen quality and treatment of male infertility $(5,6)$ but there is no well-defined therapeutical protocol.

Vitamin E has been effectively used as supplement with drugs for treatment of many diseases(7). Use of vitamin $\mathrm{E}$ has increased considerably in last decades in view of the increased awareness as regards its antioxidant and androgenic potential. Many studies have been studied in the androgenic activity of vitamin $\mathrm{E}$ in the induced testicular toxicity $(8,9)$. It was also known to induce a protective effect for testicular toxicity(11,12). Takhshid, Tavasuli, Heidary, Keshavarz and Kargar (13)reported an increase in serum testosterone level in rats treated with vitamin $\mathrm{E}$ and reducing oxidative stress in testes. (Aybek, Aybek, Rota, Şen and Akbulut (14), reported the protective effect of vitamin E on testicular function and in increasing male capacity.Since some male patient is prolonged byusing vitamin $\mathrm{E}$, the effect of prolonged use in reproductive capacity has to be investigated.

\section{Materials And Methods}

\subsection{Experimental Animals}

Forty two male albino ratsweighing 100-120 g were kept for about 15 days before the onsetof the experiment, under observation to exclude any intercurrent infectionand to acclimatize the laboratory conditions. The animals were kept inpolyethylene home cages with good aerated covers at normal 
atmospheric temperature $\left(25 \pm 5^{\circ} \mathrm{C}\right)$ and at normal daily $12 \mathrm{hrs}$ dark/light cycles. They were fedcommercial food pellets and provided with tap water ad libitum. The experiment was performed in accordance with the internationally accepted standard ethical guidelines for laboratory animal use and care as described in the European Community guidelines (17).

\subsection{Methods}

The animals divided into sevengroups, each of 6 rats.

Controlgroup: received by intra-gastric gavage tube distilled water for 90 days

Vitamin E 500 group: treated orally with $500 \mathrm{mg} / \mathrm{kg}$ b.wt.vitamin E for 90 days by intra-gastric gavage tube.

Vitamin E 1000 group: treated orally with $1000 \mathrm{mg} / \mathrm{kg}$ b.wt.vitamin E for 90 days by intra-gastric gavage tube.

Vitamin E 2000 group: treated orally with $2000 \mathrm{mg} / \mathrm{kg}$ b.wt.vitamin E for 90 days by intra-gastric gavage tube.

SVit E 500 group: treated orally with $500 \mathrm{mg} / \mathrm{kg}$ b.wt vitamin E by intra-gastric gavage tube for 90 days, then left for 45 days.

SVit E1000 group: treated orally with $1000 \mathrm{mg} / \mathrm{kg}$ b.wt vitamin E by intra-gastric gavage tube for 90 days, then left for 45 days.

SVit E2000 group: treated orally with $2000 \mathrm{mg} / \mathrm{kg}$ b.w. vitamin E by intra-gastric gavage tube for 90 days, then left to recover for 45 days.

The blood samples were collected from the medial retro orbital venous plexus of mice with capillary tubes (Micro Hematocrit Capillaries) under ketamine anesthesia for clinical chemistry assays into a plain gel tube and were standing for an hour at room temperature to obtain serum aliquots. Then the tubes were centrifuged at 5000 r.p.m for $10 \mathrm{~min}$ and the top yellow serum layer was populated off for testosterone analysis. After the blood sampling the animals were scarified by dislocation and dissected to obtain the organs for histological assays

\subsection{Determination of Serum Testosterone Concentration}

Serum testosterone $(\mathrm{ng} / \mathrm{ml})$ was determined in the serum by enzymeImmunoassay kit (Meddix Biotech Inc., 420 Lincoln Centre Drive, Foster City, CA 94404, USA, and Catalog Number: KEF4057) according to (18).

\subsection{Histological Preparation}

Immediately, after the animals were sacrificed testis of each animal were quickly excised, washed with normal saline for the removal of the blood, which might obstruct the process of fixation, blotted with filter paper, weighted and rinsed in ice-cold saline and fixed in $10 \%$ formaldehyde overnight and they were processed using standard histological methods as described by El-Hak (19). The spermatogenic seminiferous tubules and non spermatogenic seminiferous tubules counted.

\subsection{Statistical Analysis of Data}

The data were analyzed using SPSS 11.0 for Windows. The statistical significance of differences was evaluated by using one-way analysis of variance (ANOVA) followed Post-hoc Dunnettwas used to make the comparison between means. All the data were expressed in mean \pm standard error (SE) and the p-value less than 0.05 was considered significant. The percent was compared between groups using nonparametric analysis of variance (Kruskal-Wallis test) followed by Mann-Whitney U test comparing groups against each other.

\section{RESULTS}

The effect of vitamin E supplementation on the testosteronehormone in control and different treatedgroups was demonstrated in table (1).There was a significant increase $(p \leq 0.005)$ in testosterone level when the rat received vitamin at dose 1000 and $2000 \mathrm{mg} / \mathrm{kg} \mathrm{b.wt.} \mathrm{for} 90$ days, respectively.On the other hand, in the stopping treatment groups, testosterone showed anonsignificantchange compared to the control group. 
There was an increase in sperm containing seminiferous tubules when the rat received vitamin at dose 1000 and $2000 \mathrm{mg} / \mathrm{kg}$ b.wt. for 90 days, respectively, compared to the control percentage. The percentage of sperm containing seminiferous tubules in the stopping treatment group and treated rats with $500 \mathrm{mg} / \mathrm{kg}$ b.wt.for 90 daysvitamin $\mathrm{E}$ showed no difference to the control group percentage table (1).

The seminiferous tubules of control and treated rats showed normal and a small number of abnormal seminiferousFig(1). The normal seminiferous showed normal arrangement of germinal epithelium spermatogonia and Sertoli cells resting on an intact basement membrane withtypical structure of primary spermatocytes, round, elongated spermatids and late stage sperms. the abnormal seminiferous appeared with sloughing of germinal epithelium in the lumen and vacuolation in the germinal epithelium (Fig. 1-B \&1-F).
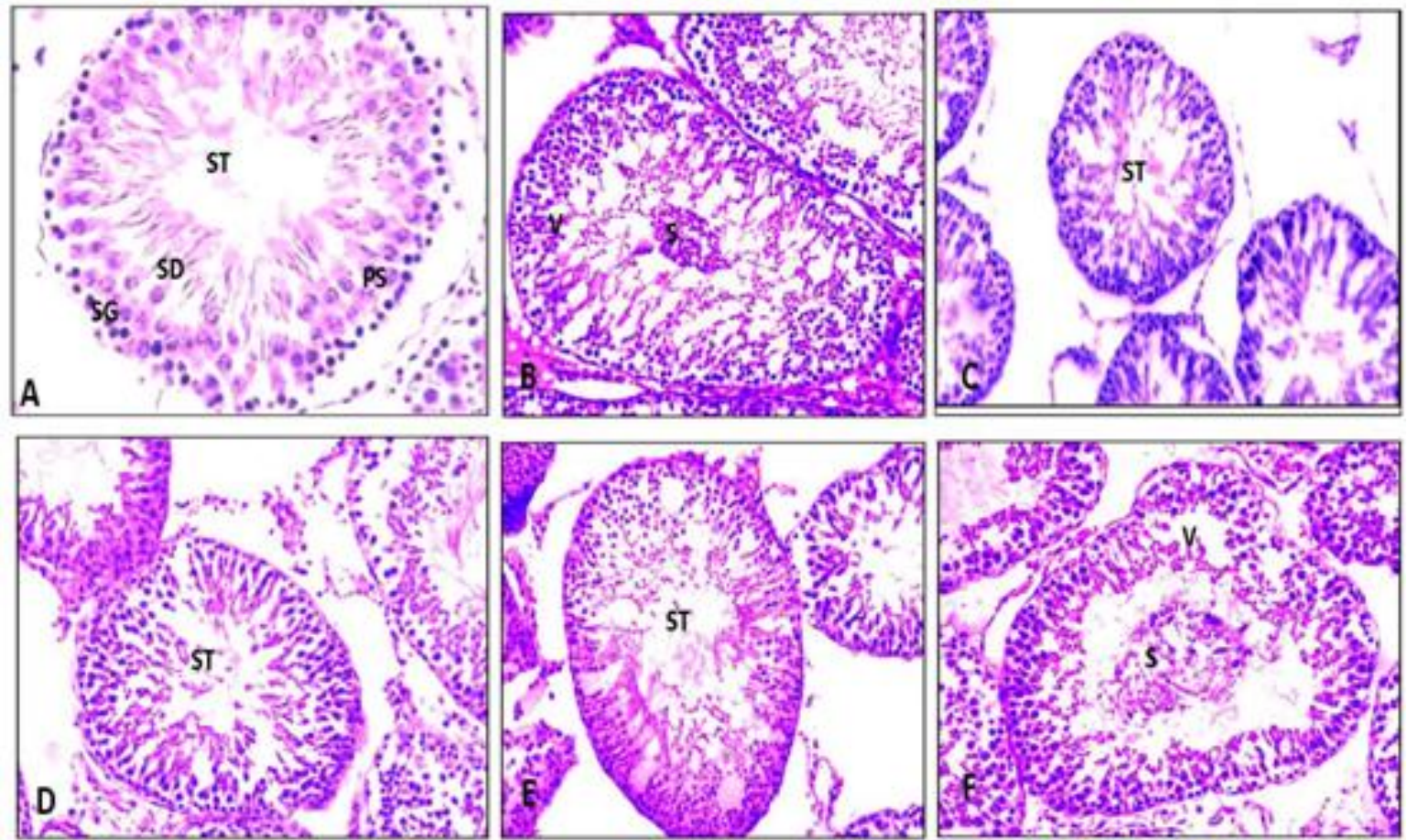

Fig(1): (A): Testis section of a control rat showing normal appearance of the seminiferous tubules (ST) with normal spermatogenesis showing spermatogonida $(S G)$, primary spermatocytes (PS), spermatids (SD). (HX \& E., $400 \mathrm{X}$ ). (B): Testis section of treated rat with $500 \mathrm{mg} / \mathrm{kg}$ vitamin E for 90 days showing seminiferous tubules with vacuolation $(V)$ and sloughing of the germinal epithelium in the seminiferous tubules lumen $(S)$. (HX \& $E$., $400 \mathrm{X})$. (C): Testis section of treated rat with 1000mg/kg vitamin E for 90 days showing seminiferous tubules (ST) with normal spermatogenesis $H X \&$ E., $200 \mathrm{X}$ ). (D) Testis section of treated rat with 2000mg/kg vitamin E for 90 days showing seminiferous tubules (ST) with normal spermatogenesis (HX \& E., 400 X). (E): Testis section of treated rat with $500 \mathrm{mg} / \mathrm{kg}$ vitamin $E$ for 90 days and left for 45 days after treatment showing seminiferous tubules (ST) with normal spermatogenesis (HX \& E., $400 \mathrm{X})$. (C). (F) Testis section of treated rat with $2000 \mathrm{mg} / \mathrm{kg}$ vitamin E for 90 days and left for 45 days after treatment showing seminiferous tubules with vacuolation $(V)$ and sloughing of the germinal epithelium in the seminiferous tubules lumen (S). (HX \& E., 400 $X)$.

Table1. Effect of treatment with vitamin E (500, 1000 and $2000 \mathrm{mg} / \mathrm{kg})$ on testosterone hormone level ( $\mathrm{ng} / \mathrm{ml})$ and percentage of sperm and non spermcontaining tubules of treated rats 90 days and stopping treatment groups.

\begin{tabular}{|l|l|l|l|}
\hline \multirow{2}{*}{ Groups } & Testosterone hormone (ng/ml) & \multicolumn{2}{|l|}{ Percentage of seminiferous tubules } \\
\cline { 3 - 4 } & Mean \pm S.E & Sperm contain & Non sperm contain \\
\hline Controlgroup: & $1.18 \pm 0.13$ & $94.72 \%$ & $5.28 \%$ \\
\hline Vitamin E 500group & $1.06 \pm 0.145$ & $84.86 \%$ & $15.14 \%$ \\
\hline Vitamin E 1000 group & $1.82 \pm 0.129^{*}$ & $98.71 \% *$ & $1.29 \%$ \\
\hline Vitamin E 2000 group & $2.05 \pm 0.133^{*}$ & $98.11 \% *$ & $1.89 \%$ \\
\hline SVit E 500group & $1.58 \pm 0.110$ & $94.82 \%$ & $5.18 \%$ \\
\hline SVit E 1000 group & $1.17 \pm 0.046$ & $94.64 \%$ & $5.36 \%$ \\
\hline SVit E 2000group & $1.06 \pm 0.044$ & $94.73 \%$ & $5.27 \%$ \\
\hline
\end{tabular}

(*) represent a significant difference between the control and treated groups.

International Journal of Research Studies in Zoology

Page | 17 


\section{DISCUSSION}

In the present study, treatment of rat with different doses of vitamin $\mathrm{E}$ for 90 days andstopping treatment for 45 days were investigated for alteration the testicular tissues and function in terms of serum testosterone level.In our study, treatment of vitamin E for 90 days caused increased spermatogenesis in the seminiferous tubules. In accordance with our finding, vitamin E can positively alter the reproductive steroid levels. Testosterone level is considered an essential indicator of testicular endocrine function (20). The result of this investigation confirmed that vitamin $\mathrm{E}$ has beneficial effects on male reproductive tissue and function by increasing testerosterone level and appearance of normal testes tissue. These fertility propertiese may be due to the androgenic and the antioxidant activities of vitamin $\mathrm{E}(21,22)$ and may be due tothe positivecorrelated effect of vitamin $\mathrm{E}$ on testosterone and the higherexpression level of steroid hormone biosynthesis enzymes (23).

The results of the present study also show that vitamin E not affect the histological structure of testes. Vitamins $\mathrm{E}$ is essential for normal spermatogenesis (24) and that in the absence of such vitamins, the animals showed dysfunction of the testis germinal layers (25). Supplementation of vitamins $E$ has been establish to reduce testicular ROS and restore normal testicular function in cadmium-exposed rats (26). Histological examination of rattestes, which received the vitamins $E$ with daily dose (500, 1000 and 2000) $\mathrm{mg} / \mathrm{kg}$ b.wt. For ninety days and after stopping the treatment. These results are being agreement to $(27,28)$.

Our finding shows that treatment with vitamin for a long time and large dose has no adverse effects on male reproductive system. Oral administration of vitamin $\mathrm{E}$ supplement in rats for 90 days has a spermatogenic effect and increase the fertility that persists even stopping treatment.

\section{CONCLUSION}

The present data suggest that vitamin E oral supplement with higher dose is safe and benefit the testicular endocrine and exocrine function. Further investigation is needed to determine the exact mechanism of increasing male fertility.

\section{REFERENCES}

[1] K. Makker, A. Agarwal and R. Sharma, Oxidative stress \& male infertility, Indian Journal of Medical Research129 (2009), p. 357.

[2] G. Dohle, G. Colpi, T. Hargreave, et al., EAU guidelines on male infertility, European urology48 (2005), pp. 703-711.

[3] S.C. Esteves, R. Miyaoka and A. Agarwal, An update on the clinical assessment of the infertile male, Clinics66 (2011), pp. 691-700.

[4] W.H. Organisation, WHO laboratory manual for the examination of human semen and sperm-cervical mucus interaction, Cambridge university press (1999).

[5] L. Keskes-Ammar, N. Feki-Chakroun, T. Rebai, et al., Sperm oxidative stress and the effect of an oral vitamin $\mathrm{E}$ and selenium supplement on semen quality in infertile men, Archives of andrology49 (2003), pp. 83-94.

[6] A. Agarwal, K.P. Nallella, S.S. Allamaneni and T.M. Said, Role of antioxidants in treatment of male infertility: an overview of the literature, Reproductive biomedicine online8 (2004), pp. 616-627.

[7] L.A. Pham-Huy, H. He and C. Pham-Huy, Free radicals, antioxidants in disease and health, International journal of biomedical science: IJBS4 (2008), p. 89.

[8] L.M. Sabik and S.S. Abd El-Rahman, Alpha-tocopherol and ginger are protective on Cyclophosphamide-induced gonadal toxicity in adult male albino rats, Basic and Applied Pathology2 (2009), pp. 21-29.

[9] E.K. Dirican and Y. Kalender, Dichlorvos-induced testicular toxicity in male rats and the protective role of vitamins C and E, Experimental and toxicologic pathology64 (2012), pp. 821-830.

[10] F.G. Uzun, S. Kalender, D. Durak, F. Demir and Y. Kalender, Malathion-induced testicular toxicity in male rats and the protective effect of vitamins C and E, Food and chemical toxicology47 (2009), pp. 1903 1908.

[11] N. Kumar, S. Sood, B. Arora and M. Singh, To study the effect of vitamin D and E on sodium-fluorideinduced toxicity in reproductive functions of male rabbits, Toxicology international19 (2012), p. 182.

[12] S. Kalender, F.G. Uzun, F. Demir, M. Uzunhisarciklı and A. Aslanturk, Mercuric chloride-induced testicular toxicity in rats and the protective role of sodium selenite and vitamin E, Food and chemical toxicology55 (2013), pp. 456-462. 
[13] M.A. Takhshid, A.R. Tavasuli, Y. Heidary, M. Keshavarz and H. Kargar, Protective effect of vitamins E and $\mathrm{C}$ on endosulfan-induced reproductive toxicity in male rats, Iranian journal of medical sciences 37 (2012), p. 173.

[14] H. Aybek, Z. Aybek, S. Rota, N. Şen and M. Akbulut, The effects of diabetes mellitus, age, and vitamin E on testicular oxidative stress, Fertility and sterility90 (2008), pp. 755-760.

[15] G. Saki, M. Jasemi, A.R. Sarkaki and A. Fathollahi, Effect of administration of vitamins C and E on fertilization capacity of rats exposed to noise stress, Noise and Health15 (2013), p. 194.

[16] M. Almbro, D.K. Dowling and L.W. Simmons, Effects of vitamin E and beta-carotene on sperm competitiveness, Ecology letters14 (2011), pp. 891-895.

[17] N.R. Council, Guide for the care and use of laboratory animals, National Academies Press (2010).

[18] A. Vermeulen, L. Verdonck and J.M. Kaufman, A critical evaluation of simple methods for the estimation of free testosterone in serum, The Journal of Clinical Endocrinology \& Metabolism84 (1999), pp. 36663672.

[19] H.N.G. El-Hak, The Protective Effects Of Panax Ginseng Extract On Fertility Of Albino Rats Treated With Formaldehyde Vapours, Egyptian Journal Of Zoology68 (2017), Pp. 221-238.

[20] . Bergmann, H.M. Behre and E. Nieschlag, Serum FSH and testicular morphology in male infertility, Clinical endocrinology40 (1994), pp. 133-136.

[21] T.A. Thompson and G. Wilding, Androgen Antagonist Activity by the Antioxidant Moiety of Vitamin E, 2, 2, 5, 7, 8-Pentamethyl-6-chromanol in Human Prostate Carcinoma Cells1, Molecular cancer therapeutics2 (2003), pp. 797-803.

[22] S. Banudevi, M. Sharmila, P. Murugesan, et al., Effects of Vitamin C and E on PCB (Aroclor 1254) induced oxidative stress, androgen binding protein and lactate in rat Sertoli cells, Reproductive toxicology19 (2004), pp. 201-208.

[23] P. Murugesan, T. Muthusamy, K. Balasubramanian and J. Arunakaran, Effects of vitamins C and E on steroidogenic enzymes mRNA expression in polychlorinated biphenyl (Aroclor 1254) exposed adult rat Leydig cells, Toxicology232 (2007), pp. 170-182.

[24] Y. Cheah and W. Yang, Functions of essential nutrition for high quality spermatogenesis, Advances in Bioscience and Biotechnology2 (2011), p. 182.

[25] A.M. Al-Attar, Antioxidant effect of vitamin E treatment on some heavy metals-induced renal and testicular injuries in male mice, Saudi journal of biological sciences 18 (2011), pp. 63-72.

[26] S. Amara, H. Abdelmelek, C. Garrel, et al., Preventive effect of zinc against cadmium-induced oxidative stress in the rat testis, Journal of Reproduction and Development54 (2008), pp. 129-134.

[27] K. BENSOUSSAN, C.R. MORALES and L. HERMO, Vitamin E deficiency causes incomplete spermatogenesis and affects the structural differentiation of epithelial cells of the epididymis in the rat, Journal of andrology19 (1998), pp. 266-288.

[28] M. JEDLINSKA-KRAKOWSKA, G. BOMBA, K. JAKUBOWSKI, T. ROTKIEWICZ, B. JANA and A. PENKOWSKI, Impact of oxidative stress and supplementation with vitamins $\mathrm{E}$ and $\mathrm{C}$ on testes morphology in rats, Journal of Reproduction and Development (2005), pp. 0512260033-0512260033.

Citation: Heba N. Gad EL-Hak et.al.," Effect of Subchronic Vitamin E Treatment on the Testes of Male Albino Rats", International Journal of Research Studies in Zoology, vol. 5, no. 2, p. 15-19, 2019. DOI. http://dx.doi.org/10.20431/2454-941X.0502003

Copyright: (C) 2019 Authors. This is an open-access article distributed under the terms of the Creative Commons Attribution License, which permits unrestricted use, distribution, and reproduction in any medium, provided the original author and source are credited. 